\title{
The Cause That Refreshes:
}

\section{Reading, 'Riting, and Rebellion}

$\mathrm{H}^{\prime}$ ISTORY DorS NOT REFAAT TISELF. The repetition is only that the mistakes of one generation are too often imitated by the next. There are lessons in a knowledge of the past: How can we abide the present, how can we face the future, unless we know what has gone before? Yet, if history fails to repeat itself, there is in it a national remembrance that gives us national character.

In the thorough knowledge of the history of one time and place there is a suggestion, no matter how invalid, that the present does repeat the past. There is a deep and strong impression of the immediacy that links past, present, and future. There is a sense of the immediacy of history, or of the present as the durable past, in the words a Chicago Times correspondent wrote describing the entry of Federal troops into Little Rock, Arkansas, in 1863: "An army was never more astonished upon entering a city than ours was upon its entry of Little Rock. Instead of a warm, cordial welcome from the citizens, we were greeted at best with a cold, frigid politeness. ... A cold, haughty stare met your gaze upon every side, and no sign of genuine welcome was visible anywhere."

Was 1863 very different from 1957 ?

April 14, 1865 was the fourth anniver-

$M r$. Harwell is Executive Secretary of ACRL and Associate Executive Director of ALA. This article is adapted from a paper presented at a meeting of the College, University, and Research Libraries Section of the California Library Association, Long Beach, Calif., October 29, 1958. sary of the fall of Fort Sumter. Federal officials made that date the occasion of a grand celebration reraising over the ruined fort the same flag which had flown during Major Robert Anderson's gallant defense of it at the beginning of the War. President Abraham Lincoln was expected to attend, but the press of duties kept him in Washington, and he chose that evening to attend a performance at Ford's Theater. Anderson, now a general, did participate in the ceremonies, and the principal address of the occasion was delivered by Henry Ward Beecher, then the most famous, later the most notorious, pastor of his day.

Is it a message of the past, the present, or the future that lies in Beecher's words there in Charleston Harbor? "We have shown," he declared, "by all that we have suffered in war how great is our estimate of the importance of the Southern States to this Union, and we will honor that estimate now in peace by still greater exertions for their rebuilding. Will reflecting men not perceive, then, the wisdom of accepting established facts, and with alacrity of enterprise begin to retrieve the past? ... Since free labor is inevitable, will you have it in its worst forms or its best? Shall it be ignorant, impertinent, indolent, or shall it be educated, self-respecting, moral, and self-supporting? Will you have men as drudges, or will you have them as citizens? Since they have vindicated the Government and cemented its foundation stones with their blood, may they not offer the tribute of their support to maintain its laws and its policy? It is better for religion, it is better for political integrity, it is better for in- 
dustry, it is better for money, if you will have that ground motive, that you should educate the black man, and by education make him a citizen. They who refuse education to the black man would turn the South into a vast poorhouse, and labor into a pendulum."

There is a very real immediacy for bookmen in the history of the American Civil War. For the last twenty-five years there has been an accelerating interest in it on the part of writers, publishers, and readers. The centennial years ahead will emphasize and broaden this interest. Not all interest in Civil War history has developed from worthwhile motivation. Some is the product of too strong a dose of filiopietism, particularly some of the Southern interest. Some is the interest of rootless Americans of later generations seeking to identify themselves with their country's past. Some is crassly commercial. But interest per se is worth while, and the diversity of present interests certainly makes worth while the breadth of Civil War scholarship and publishing that marks our decade.

Books about the Civil War are published at an alarming rate. In 1958 there were about two published each week. The 1959 total will probably equal that of the previous year. There are those who decry the volume of Civil War publishing. True, there are too many meretricious, catch-penny publications. The professional writers, the reporters, the hacks have recognized a good thing and have got into the act. But this is a healthy sign. It is the strongest possible evidence of the breadth and depth of interest in the Civil War. A subject loses none of its value simply because it catches the fancy of the crowd. Perhaps some interest is superficial, but it is interest; and it is for those who work with books to use it as a wedge to create a better grounded interest. It is a healthy sign because the professional writers, the reporters, the hacks can write. They are writers first, historians after. They have an eye for the dramatic and a way to tell a story. They have invaded the field of the professional historian, and the writers and the historians have contributed one to the other. The writers have been guided to good historical subjects, and the historians have learned to write more interestingly. Everybody benefitswriters, historians, publishers, readers, and, perhaps, even librarians.

Of Civil War literature the beginning was a long time ago. Although the coming of the War was predicted in even earlier fiction, the only prophetic novel of note is Beverley Tucker's The Partisan Leader. The Partisan Leader was published in Washington in 1836 with a fictitious imprint dated 1856 . With uncanny accuracy in detail it foretold the course toward disunion and war. It is a poor novel, but it retains a certain charm for die-hard Confederates in the large point on which it erred; in the pages of The Partisan Leader it was the Southern Confederacy that won the War. The War brought all kinds of publications. They provide a fertile field for collectors, librarians, bibliographers, and historians.

Civil War collecting is almost coetaneous with the War itself. The Harvard College Library began systematic collecting activities in 1861. So did the Alabama State Library. "The war is storing up, for the people of the Confederate States, the noblest legacies that ever fell to the lot of Nations and Communities," declared Richmond's Magnolia Weekly. What was true for one side was essentially true for both and was as true of printed materials as of individual or regional traditions. Both sides could well have heeded the admonishment of the Magnolia: "It behooves our people to guard these legacies, that desolating war shall have left them, with jealous care." But jealous care of its printed legacies was hardly to the tenor of thinking in the South in the years just after the War. 
There was much that was better forgot. And livings had to be made. Book collecting could wait. Thus the earliest great collections grew up in the North. Northern libraries accumulated in their normal growth the principal items of Union interest. The greatest of Confederate collections (that at the Boston Athenaeum) had its beginnings in purchases Francis Parkman made in Richmond in the spring of 1865 . Documents captured at the fall of Richmond became the basis of the great Confederate collection now at the Library of Congress. Appreciation of the abiding value of these records was demonstrated only shortly after the War in a General Order from the United States War Department authorizing "That a Bureau be organized in the Adjutant General's Office for the collection, safe-keeping, and publication of the Rebel Archives that have

One of the greatest favors to the future historian and philosopher would be to collect all the books, pamphlets, maps, files of newspapers, engravings, photographs, caricatures, ephemeral publications of every kind, even to printed notices, circulars, handbills, posters, letter envelopes, and place them beyond the reach of destruction, that as a collection they may reflect the sentiments and feelings, which otherwise will in a great measure pass into oblivion with the occasions which give them birth. If I could, I would appeal to every inhabitant of the continent to send me everything which could be obtained, in order that every phase of mind, in every section of the country, North, South, East, West, for the Union and against the Union, for secession and against secession, might be represented on our shelves, in all the variety of reasoning and imagination, virtue and vice, justice and injustice, fiction and fact, freedom and oppression, kindness and cruelty, truth and caricature, that can be found. I would say, send to me a single pamphlet, book, or picture, if you have one to spare.-John Langdon Sibley in Report of the Committee of the Overseers of Harvard College Appointed to Visit the Library for the Year $1861 \ldots$ (Boston, 1862). come into possession of this Government." Collections begun by Union soldiers during the War eventually found their way into libraries and form the core of fine and extensive holdings at Princeton, the Western Reserve Historical Society, the Newberry Library, and the Chicago Historical Society. The Civil War collection of John Page Nicholson, do not command the high prices of First Folios or even of the better Western Americana, they have a special charm and, to their own inamoratos, an intangible value beyond measure. The popularity of Civil War collecting increases. A spot check of a recent issue of the Antiquarian Bookman shows 156 Civil War items advertised as wanted and includes 
a dozen dealers advertising general wants in the field. The War runs a poor second to sex among the $A B$ 's ads, but ahead of almost every other subject.

The South at war published more than seven thousand bibliographical items. Many of these items are of the most minor sort, but some are productions impressive in extent and quality. They are the expressions of every aspect of a country at war, a library to demonstrate the social as well as the military impact of war on a people. People at war rush into print to vent their emotions. Preachers turn out sermons of justification of their viewpoint. Extremists expound their theories in broadsides and pamphlets. Amateur poets and song writers have a field day in an era of violent feeling. It is not remarkable that a people at war should publish extensively; it is a necessity that they do so. It is remarkable that the Southern Confederacy devoted so large a proportion of its publishing time and energy to the non-warlike in its literature-to more than a hundred items of belles-lettres, to more than seven hundred sheets of music, to books of travel, to volumes of ancient history.

Let us call our Confederate witnesses.

An anonymous contributor to The Southern Field and Fireside, a Confederate literary weekly published at Augusta, Georgia, declared: "This ought to be a halcyon period for authors as there has not been a time for many years so abundant in materials for writing as the present. Indeed the trouble is not to find subjects and matter, but to know what is best to select from such a mass as has accumulated in the past few years. Historians have a wide and attractive field to traverse . . Biographers can select from warriors, statesmen, persecuted refugees, patriotic citizens and noble women, and when scores have written for years, will still find many names worthy to be perpetuated . . Poets will find themes for lofty song, and collectors of facts and wonders will have an inexhaustible field for exploration. Refugees will have stirring incidents to relate; soldiers strange, wild and dangerous adventures; and sailors will startle with marvelous tales of what befell them on the wide ocean, in foreign ports, or in running into our own beleaguered ones beneath showers of shot and shell. Fancy will find itself eclipsed by facts; and fiction ... will not need to call on imagination to paint her picture, but will only have to arrange and decorate the attire of the principal figures. All these things, together with the current events of the day, must aid in enriching the newspapers as well as form the books for the million."

Sidney Lanier, the Georgian poet and musician, caught the spirit of the South as it went to war in his novel Tiger Lilies, a book begun in the intervals of its author's duties as a Confederate signalman: "In the spring of 1861 an afflatus of war was breathed upon us. Like a great wind, it drew on and blew upon men, women, and children. Its sound mingled with the solemnity of church-organs and rose with the earnest words of preachers praying for guidance in the matter. It sighed in the half-breathed words of sweethearts. ... It thundered splendidly in the impassioned appeals of orators to the people. It whistled through the streets, it stole in to the firesides, it clinked glasses in bar-rooms, it lifted the gray hairs of wise men in conventions, it thrilled through the lectures in college halls, it rustled the thumbed bookleaves of the school-rooms.

"This wind blew upon all the vanes of all the churches of the country, and turned them one way-toward war. It blew, and shook out, as if by magic, a flag whose device was unknown to soldier or sailor before, but whose every flap and flutter made the blood bound in our veins."

Lanier felt the emotional impact of 
the beginning of war and, he thought, of a new nation. William Gilmore Simms, dean of Southern novelists of the period, conveyed its continuing meaning in words he wrote in his introduction to an anthology of Confederate poetry published soon after the War: "The emotional literature of a people is as necessary to the philosophical historian as the mere details of events in the progress of a nation. . . . The mere facts of history do not always, or often, indicate the true animus of the action. But in poetry and song, the emotional nature is apt to declare itself without reserve-speaking out with a passion which disdains subterfuge, and through media of imagination and fancy which are not only without reserve, but which are too coercive in their own nature, too arbitrary in their influence, to acknowledge any restraints upon that expression, which glows or weeps with emotions that gush freely and freshly from the heart."

It is that "true animus" in which librarians, historians, and bibliographers are most interested. It is that feeling of the time they wish to discover. Librarianship, historingraphy, and bibliography are but tools, and are but poor tools if they do not lead to that animus, if they teach only to shelve books, record facts, or list titles.

Not only the emotional literature, but the whole scope of printed evidence of life in the Confederacy is an index to the feelings and actions of the time. The Confederate States can serve as a remarkable laboratory for the study of the sociological impact and importance of the printed word. It was a nation circumscribed in both time and area. It was a nation in which printing had become a part of everyday life but where the products of the presses had not reached an unmanageable abundance. The printed evidences of the Confederates-government publications of laws, battle reports, general orders, instructions for petty off- cials; the news accounts of victories and defeats; biographies, sermons, novels, plays, song-sheets, broadside petitions and advertisements, playing cards, religious tracts, and railroad schedules-are abiding testimonials of how the Confederacy lived and fought.

Four and a half years is a short time in which to produce a national literature. In the face of the difficulties that beset authors, publishers, and readers it is surprising that the Confederate States produced any literature at all. The flowering of Southern letters came later, but there were foreshadowings during the War. Lanier was writing Tiger Lilies. Joel Chandler Harris, then a printer's devil, was contributing his first verses to the columns of The Countryman, a plantation paper which brought a flavor reminiscent of The Tatler to middle Georgia. John Esten Cooke, unofficial aide-decamp of J. E. B. Stuart, was sending as despatches to Richmond's The Southern Illustrated News much of the material later reworked into novels of the Army of Northern Virginia. Constance Cary was composing stories for the Richmond journals (though they show little of the finish that marks her later novels). Augusta Jane Evans was nursing soldiers at Camp Beulah near Mobile and using her spare time to write Macaria, literary sensation of the last years of the Confederacy.

The first Confederate publications consisted largely of political pamphlets, the proceeedings of the secession conventions of the several Southern states, and an impressive library of military manuals designed to bridge the translation of civilians into an army. The first Confederate copyright (later rescinded) was granted to S. H. Goetzel's edition of General William J. Hardee's Tactics early in 1861. At least three volumes of Southern poetry and one book of camp humor made their appearance by the end of the year. New novels were not ready until 
1862, but, as supplies of old titles in bookshops dwindled and readers turned from the temporary excitement of political pamphlets to more entertaining reading, the flow of both domestic and imported fiction was impressive.

Confederate publishing grew into a booming business. One firm, the Evans \& Cogswell Company of Columbia, South Carolina, operated an establishment with seventy-six presses and 344 employees. Even so, editions were small and distribution was haphazard. Shortages necessitated use of native hardwoods instead of metal in making plates. Books were bound in wallpaper. Newspapers borrowed paper on virtually an issue-to-issue basis, printed on wallpaper or coarse wrapping paper; and few issues were missed. The peripatetic career of the Memphis Appeal has long been a saga of journalism. Many other papers were published far from their homes. After appearing in Georgia for some time, the refugee Winchester, Tennessee, paper finally sold its press to the Medical Department of the Army of Tennessee. Ususually housed in a boxcar, this press spent the last two years of the war grinding out general orders and medical forms at a variety of spots in Georgia, Alabama, and Mississippi.

Most popular of Confederate periodicals was The Southern Illustrated News. Established in Richmond in the early fall of 1862 the News presented its readers a galaxy of distinguished writers and soon achieved unprecedented success for a Southern weekly. It had a capable editor in John R. Thompson. It maintained its own staff of artists and engravers. Best of all, it paid for contributions. Among its contributors were Thompson (who was also State Librarian of Virginia at the time), Simms, Cooke, Henry Timrod, Miss Cary, and Paul Hamilton Haynethe cream of the practicing literary figures of the Confederacy.

The News was modelled after the $I l$ - lustrated London News. In like manner Southern Punch was, in its own words, "a legitimate son of that world-renowned 'London Punch'. . . . Our 'Punch' is a genuine Confederate. He prefers the Virginia mint julep and the mixed drinks of the Cotton States to Brown Stout and Cheshire cheese. In a word, the young Punch is Southron."

The whole literature of the Confederate States was Southern-because of a deep consciousness of the historic moment in which the Confederacy lived. "There is a deeper pathos, a loftier poetry," wrote the Illustrated News, "in the incidents of yesterday's battlefield than belong to the most tuneful measures, while Jack Morgan and Jeb. Stuart surpass all the knighthood of romance." Mrs. Sallie Rochester Ford seized on the exploits of Morgan to create her Raids and Romance of Morgan and His Men. Cooke's "Outlines From the Outpost," sparkling reports from Stuart's camp, served as seed corn for such novels as Surry of Eagle's-Nest, Mohun, and Hilt to Hilt. Frank R. Goulding re-wrote his Robert and Harold into the text beloved by four generations of Southern youngsters as The Young Marooners. George William Bagby wrote humorous stories for Confederate periodicals in the strain that later made him famous. With $\mathrm{Ma}$ caria (a novel for which General P. G. T. Beauregard acted as military adviser) Miss Evans apprenticed her postwar success St. Elmo, verily the Gone With the Wind of its day.

There were meretricious stories too, hack productions by James D. McCabe, Jr., W. D. Herrington, Mary Jane Haw, Alexander St. Clair Abrams, Napier Bartlett, Ebeneezer Warren, and others. They turned out the fragile booklets the soldiers bought in railroad stations, read to death, and made forever rare. There were plays by Joseph Hodgson, McCabe, Stephen F. Miller, and William Russell Smith-of little dramatic worth but ex- 
pressive of the time. And poetry. The literary South did its best in the topical poems of Hayne and Timrod, Thompson, Cooke, Simms, James Ryder Randall, Severn Teackle Wallis, Lynden Flash, John Hill Hewitt, and a host of "female poets." Southerners who know little of history and even less of literature still remember schoolboy recitations of "The Burial of Latane,", "The Battle Rainbow," "Little Giffen of Tennessee," and "The Broken Jug." Even those who do not know it was first a poem recognize the stirring words of "Maryland, My Maryland." One Confederate anthologist boasted in 1862: "Southern independence has struck the lyre as well as unsheathed the sword," and then, in a naively candid sentence, added: "The book embalms if it does not immortalize."

The Confederacy's literary accomplishments proved that the seeds of a regional, if not national, literature were among her people. They proved once again that a people lives not by bread alone, nor by battles alone. They left for Americans of later generations a living record of the Confederate States.

Was the story of printing and publishing activities of the North during the War years very different from that at the South? Probably not. One of the boons in studying Civil War history is that soldiers and civilians on both sides spoke the same language, dressed alike and wrote alike, and generally lived and thought alike. As President Lincoln put it, "They read the same Bible, and pray[ed] to the same God, and each invoke[d] His aid against the other." They were-despite different turns of political opinion-in fact, alike; something they may someday rediscover.

As were their opponents at the South the Northerners of the sixties were tremendously conscious of their moment in history. There was a national urge to record the experience of war at every level of activity. This breadth of expression from both sides eventually combined with the work of later historians to make the American Civil War the best documented of all wars.

America in 1861 was still a new country. Just as the War was a test of democratic principle, it was a test of democratic education. Never before had there been so literate an army as that of the United States. Such a soldiery was ready and proud to relate its experiences. Such a soldiery was capable of understanding printed orders and explanations. Nor, in the newness of universal education, was this country, as Beecher noted, "with books and newspapers thick as leaves in our own forests" inured to the uses of propaganda. It was ripe for the printed word to be used in shaping the course of its history.

Unlike their Southern contemporaries, the Northerners were not impoverished for the materials of printing as the War progressed. Printing did not disappear at the South, but it survived despite difficulties that seriously hampered its effectiveness. In the North, supplies of paper, presses, and printers were readily available throughout the War. The publishing business was not nearly so concentrated in the big cities of the East as it would be later; nor was a discouragingly large capital investment required to engage in it. There were publishers in the new cities of the Midwest, in Denver, and even in far-away San Francisco. Presses were soon adapted to camp use so that many military units had their own regimental papers and every major command its own field press.

Nor was the United States impoverished of authors. Though little of literary note was published during the War, there was a wealth of talent among the practicing writers of the time. Some of this talent, such as Walt Whitman's, was directed into active participation in the War. Other was used for the creation of 
literary propaganda. Lowell, Whittier, and Holmes were active propagandists. Even Bret Harte in the Far West wrote a special poem for The Sanitary Commission Bulletin. Edmund Clarence Stedman reported the War for the New York World and wrote topical poetry. Others who contributed to the anthologies of the day included Thomas Bailey Aldrich, Charles G. Leland, and FitzJames O'Brien. The wartime novels were undistinguished, but there was a plenty of them. The magazines-Leslie's, Harper's, the Atlantic-flourished. J. W. DeForest, later to achieve a distinguished reputation as a novelist, wrote reports from the armies for Harper's, and the Atlantic printed one of its most enduring stories when it published Edward Everett Hale's "The Man Without a Country." Stephen Foster, Henry Clay Work, George F. Root, Patrick Gilmore, and other professional song writers supplied music for the soldiers; but amateurs helped, particularly Julia Ward Howe with the great "Battle Hymn of the Republic." And, of course, the War was thoroughly documented in publications of Congress, personal and official reports of generals, and in publication in newspapers of every scrap of information reporters with the armies could uncover.

In the printed page we have the story of the American Civil War as it was lived by the participants. In the printed page is the immediacy of history. For there need be little more between the author of the 1860's and his reader of the 1950's than there was between him and the reader of his own day. For our best understanding of the War we turn, not to the multitude of latter-day interpretations, but to the interpretations of its own time- - to the past itself.

Again I call contemporary witnesses.

Where better than in the letter General Robert E. Lee wrote to a little girl in the North in May 1861 is an expression of the attitude of that great man?
"May God," he wrote, "reunite our several bonds of friendship, and turn our hearts to peace! I can say in sincerity that I bear animosity to no one. Wherever the blame may be, the fact is that we are in the midst of a fratricidal war. I must side either with or against my section of the country. I cannot raise my hand against my birthplace, my home, my children."

Here are excerpts from the words General William Tecumseh Sherman wrote the Mayor of Atlanta in the late summer of 1864: "We must have Peace, not only at Atlanta, but in all America. To secure this, we must stop the war that now desolates our once happy and favored country. To stop war we must defeat Rebel armies that are arrayed against the Constitution which all must respect and obey. ... You cannot qualify war in harsher terms than I will. War is cruelty, and you cannot refine it; and those who brought war on the country deserve all the curses and maledictions a people can pour out. I know I had no hand in making this war, and I know I will make more sacrifices to-day than any of you to secure peace. But you cannot have peace and a division of our country.... I want peace, and believe it can only be reached through Union and war, and I will ever conduct war purely with a view to perfect and early success."

And should any American ever forget the words of President Lincoln's Second Inaugural? "Fondly we hope-fervently we pray-that this mighty scourge of war may speedily pass away," he said. And then, in an incomparable peroration: "With malice toward none; with charity for all; with firmness in the right, as God gives us to see the right, let us strive on to finish the work we are in; to bind up the nation's wounds; to care for him who shall have borne the battle, and for his widow, and his orphan-to do all which may achieve and cherish a just and a lasting peace among ourselves, and with all nations." 